\title{
TRANSMEDIAL COLLABORATIVE PRODUCTIONS IN SECRET PATH AND AIRPLANE MODE
}

\author{
Camila Figueiredo* \\ Editora Universidade Federal de Minas Gerais, MG
}

\begin{abstract}
The term "transmedia" has gained popularity in the entertainment industry and has been widely used to designate the use of several media platforms that converge to tell a story. As a result, transmedia changes the modes of consumption and production of contemporary cultural products. On one hand, transmedial projects attract consumers that are no longer just readers or players (or users, spectators, etc.), but are a combination of them. On the other hand, these projects often require "superproducers" or "superartists", with knowledge and skills in various media, or a wellplanned collaboration between producers or artists. In this article, we will examine the collaborative productions in the Canadian Secret Path (2016) and in the Brazilian Airplane Mode (2017) transmedial projects.

Keywords: Transmedia; Transmedia Project; Transmedia Franchise; Secret Path; Airplane Mode.
\end{abstract}

"Doctor in Comparative Literature from Universidade Federal de Minas Gerais (UFMG), Brazil. Her research focuses on Intermedial studies, with an emphasis on Transmediality and Adaptations. She currently works at UFMG Publishing House (Editora UFMG), as Editorial Manager and Vice-Director. Her email address is camilafig1@gmail.com. 
The term "transmedia" has gained popularity in the last decade in the entertainment industry and has been widely used by artists, producers, brands, game developers and critics. The expression that originated it, "transmedia storytelling", was first used by Marsha Kinder and Mary Celeste Kearney as a promotional practice involving merchandising, adaptations, sequels and franchises (Evans 20-21).

Transmedia designates the use of several media platforms that converge to tell a story. Since a single text could not cover all the content of the narrative, a central text (usually a novel or a film) offers several points of access to the plot, which are explored in other media such as digital games, comics, websites, online videos, blogs, social networks, etc. In an ideal case of transmedia storytelling, there is no redundancy of information, but each medium offers new levels of revelation, which come together to compose the complete narrative of the franchise.

The most common definition used to describe the transmedial phenomenon is the one Henry Jenkins proposed in 2003 for the journal Technology Review, which was later taken up in his book Convergence Culture. For Jenkins, transmedia [at that moment "transmedia storytelling"] designates a new kind of narrative, in which the story "unfolds across multiple media platforms, with each new text making a distinctive and valuable contribution to the whole" (Convergence 9596). He also states that this flow of content across multiple media channels is almost inevitable in this age of media convergence.

Transmedia is based on a triad: media convergence, participatory culture and collective intelligence. Media convergence takes place through "the flow across multiple media platforms, the cooperation between multiple media industries, and the migratory behavior of media audiences"; convergence does not occur through the union of devices, but "within the brains of individual consumers and through their social interactions with others." (Jenkins, Convergence 2-3) Participatory culture contrasts with the notion of passivity of the spectators, who abandon the role of mere consumers of media products and begin to participate, interact and even produce their own media content. The expression "collective intelligence", coined by the French theorist Pierre Lévy, refers to the strategy of consumption capable of dealing with the great flow of information of our days: "[b]ecause there is more information on any given topic than anyone can store in their head, there is an added incentive for us to talk among ourselves about the media we consume" (4). First, information is collected according to individual resources and abilities; later, in a similar way to what we do with the pieces of a jigsaw, those pieces of information are put together.

In his blog Confessions of an Aca-Fan, Jenkins describes the phenomenon as "one logic for thinking about the flow of content across media" (Transmedia n.p.). In practice, therefore, transmedia is a strategy normally used to (a) bridge the main text - usually the film - and its sequences; (b) foretell evolutions in the plot; (c) expand the narrative or complete its gaps; (d) develop stories of secondary characters, other details and perspectives of the narrative; (e) offer support for 
a new public to get to know the franchise; (f) build universes that cannot be exhausted in a single medium. Economically, this is an interesting project for producers, as it ends up attracting consumers from different niches and increasing audience engagement. Thus, the understanding of the transmedial narrative occurs in the intersection of several media, in an inter- and multitextual network system that will generate an amplified and complex interpretive experience. This is one of the main characteristics of the transmedial phenomenon.

Later on, Jenkins revisits the concept, extending it beyond the narrative. Thus, the author begins to understand the phenomenon as the expansion of content in several platforms in a cohesive way, creating a fictional world that can reach consumers of different media. Following this new conception, "transmedia storytelling" or "transmedia narrative" has been gradually replaced by the general term "transmedia", which has been used not only by narratologists, but also by journalists, marketing and media professionals, as well as by teams specialized in the creation of transmedia content for promotion and dissemination of a particular product or set of media products.

The use and study of transmedia have become popular in the last two decades because of, among other factors, the various functions that it can assume, as well as for being characterized as a transdisciplinary phenomenon, which serves as object of study for several areas such as Linguistics and Literature, Communication, Journalism and Marketing. This is because transmedia reflects the new ways of telling, retelling and consuming (listening/watching/watching/ playing etc.) stories, typical of contemporary times and which results from the different types of and access to new media. ${ }^{1}$

This means that, in processes of media convergence, besides the development of cohesive multiplatform texts, it is also necessary to think about the kind of experience that will be offered to audiences, which includes the modes of engagement that will be demanded from fans, the technologies available, the schedule of the transmedia project and the type(s) of audience(s) expected to be reached.

Transmedial dynamics change the modes of reading and consumption of books, for example. In many cases, book audiences are no longer restricted to the readers, but they probably (if the transmedial project succeeds) also include the player, the Internet user, the spectator, or - using a term coined by Janet Murray (1998) to designate one who participates in the construction of a cybernarrative the "interactor". It is imperative to look at this new audience, to the new skills that new media require from them and to the way they receive and have access to this type of transmedial production. And, of course, it is important that publishers who develop transmedia projects keep in mind that reading the book will be only a part of their audience's experience with the narrative or, in other words, that the book will be only one of the products that will be consumed.

Transmedia, however, impacts not only the mode of consumption but also the mode of production of contemporary cultural products - my focal point in this text. There is nowadays a new logic of production and distribution of these projects, which results in other forms of circulation, marketing and consumption 
of cultural products. In practical terms, this means that it will probably be necessary a bigger team of producers and writers, literary (or multimedia) agents, with contracts that allow legal and commercial aspects in several platforms.

For example, in the film industry, the Matrix franchise project can be considered an example of "entertainment for the age of media convergence, integrating multiple texts to create a narrative so large that it cannot be contained within a single medium", as Jenkins declares (Convergence 95). Because of the transmedial project developed for the Matrix franchise, in order to fully understand its story, it is not enough to watch the three movies; we also need to read the comics, watch the anime, play the video game and the multiplayer online game - MMOG. All these media were used to tell different parts of the story.

The effects of this new demand were felt more intensely in 2007, when there was a strike by script writers demanding compensation for the creation of transmedial content in American television because this was, from their point of view, an integral part of the creative development of the program - and not just promotional content, as the producers believed. In 2010, the Board of Directors of the Producers Guild of America - PGA, which represents producers of television, film and new media, defined the transmedia franchise or project and approved the inclusion of the "transmedia producer" in its Credits Code, a manual that guides and describes the roles and responsibilities of the professionals involved in the production of content in these media.

The Guild then defined a transmedia franchise or project as one that consists

of three (or more) narrative storylines existing within the same fictional universe on any of the following platforms: Film, Television, Short Film, Broadband, Publishing, Comics, Animation, Mobile, Special Venues, DVD/Blu-ray/CD-ROM, Narrative Commercial and Marketing rollouts, and other technologies that may or may not currently exist. These narrative extensions are NOT the same as repurposing material from one platform to be cut or repurposed to different platforms.

And, according to the same manual, the transmedial producer was therefore designated responsible

for a significant portion of a project's long-term planning, development, production, and/or maintenance of narrative continuity across multiple platforms, and creation of original storylines for new platforms. Transmedia producers also create and implement interactive endeavors to unite the audience of the property with the canonical narrative and this element should be considered as valid qualification for credit as long as they are related directly to the narrative presentation of a project. (Producers, n.p.)

This recognition of the role of the transmedia producer confirmed the necessity for new labels and roles, in compliance with the context of media convergence and reaffirmed the importance of this professional in the American movie industry. 
More aligned with the marketing field, transmedia producer Jeff Gomez describes this new professional as an "universe administrator", someone responsible for various intellectual properties and for coordinating and guiding a brand across multiple platforms in the creative arena. In addition, it is up to him to "(...) respect universe above and beyond studio politics, above and beyond licensing, above and beyond even the producers, directors and actors who are involved in creating individual components of this universe." (qtd. In Dena 128)

In many cases, this "universe administrator" or "superproducer" is responsible for facilitating communication between his/her team's creative professionals and supervising the project, making sure that all the initiatives created within it keep the same look and expand the universe consistently. These professionals must therefore attest the presence of two fundamental elements for transmedial projects: continuity and coherence. This implies keeping the same "creative vision" in various products, such as movies, comics, digital games, websites, TV series, plays, but also in posters and licensed products, which can be challenging, especially in projects which involve large teams and various media.

Working on a transmedial project, therefore, requires not only knowledge of the specific mechanisms related to the functioning of a medium, but also skills and decision making in areas such as design, human resources, negotiations, copyright laws and marketing strategies in various media. Because of these multiple requirements, it is becoming an increasingly common practice to hire companies that plan and execute transmedial projects. In these companies, we observe the emergence of professionals who specialize in the typical dynamics of transmedia, such as writers or screenwriters working in various media, who join forces with designers and producers working for synergy and convergence among various platforms.

Although it is more common in the movie industry, this transmedia professional also acts in other markets. It is easy to notice, for instance, that some publishers have not only been concerned with the publication of printed books lately, but they have also been looking for professionals with skills in several different media, people who can act and establish partnerships in different media markets. Thus, the assistant editor or chief editor becomes a manager of content in multiple platforms, not just the print medium.

In this sense, Simone Murray states that the publication of a book nowadays has from the beginning a multimarket character, one that should foresee adaptations, different editions and formats of that text (37-42). Many publishing contracts already include translations, e-book versions, audiobooks, representation or adaptation rights (films, television series, theater, radio, novelizations, digital games, graphic novels, animations, etc.), short versions, anthologies, sequels, prequels and spin offs.

One could say the same of authorship, which is no longer restricted to a single medium, much less to the print one. Particularly common nowadays is writing a novel with the intent to be adapted into a film, something desired and often planned from the earliest stages of book production: an author writes both a book and a screenplay or even writes a book with the characteristics of a script. 
As one might also expect, transmedia projects involving literature and comics or that have any of them as their mothership (that is, the main medium, the one which offers the points of access to other media within the franchise) have also played an important role in the book market - and also the ones for other media. As illustrative of these kinds of projects involving transmedial collaboration, we have chosen to examine two very recent cases: the Canadian production of Secret Path (2016) and the Brazilian Airplane Mode (2017). As we will observe, although they apparently do not have much in common, they were both conceived and are organized in a transmedial and collaborative fashion.

\section{The Secret Transmedial Path}

Gord Downie was a Canadian rock musician, born in 1964, lead singer for the band The Tragically Hip, and deeply involved in environmental movement, especially issues concerning water rights. His final years, however, were dedicated mostly to indigenous affairs.

In September 2016, just four months after being diagnosed with a terminal brain tumor, the artist announced the release of a solo album called Secret Path, a project he had been working on since 2013. In a statement at the project's website, Downie explains how the idea for the project came to him: "Mike Downie [his brother] introduced me to Chanie Wenjack; he gave me the story from Ian Adam's Maclean's magazine story dating back to February 6, 1967, 'The Lonely Death of Charlie Wenjack"' (Statement by Gord Downie, n.p.).

Chanie Wenjack was a twelve-year-old boy who died on October 22 $2^{\text {nd }}, 1966$, after escaping from the Cecilia Jeffrey Indian Residential School near Kenora, Ontario. After the escape, Chanie (miscalled "Charlie" by his teachers) walked the railroad tracks trying to reach home, located over 640 kilometers away from the Residential School.

The Residential school system was formed by a group of boarding schools for indigenous people funded by Canadian Government's Department of Indian Affairs in 1876 and administered by Christian churches. It was created with the purpose of removing children from their parents, community and own culture, and assimilating them into the dominant Canadian culture. The last federal residential school closed in 1996.

The schools were intentionally located far from the indigenous communities so as to minimize contact between children and their families. The system is now heavily criticized for disconnecting children from their ancestral languages by forcing them to speak English or French as well as depriving them from their own cultural and religious roots. There have also been reports that many of them were exposed to physical and sexual abuse during their time at residential schools. Although numbers are not precise, it is known that the system hosted more than 150,000 children, and that at least 3,200 (some would even say 6,000) died from diseases and malnourishment. Besides long-term traumas, children who managed to graduate from residential schools were said to experience 
dislocation, as they were enable to adapt neither to European-Canadian or to the indigenous societies.

Secret Path is an initiative that acknowledges a dark part of Canada's past, one that has been largely ignored, as Downie explains:

Chanie haunts me. His story is Canada's story. This is about Canada. We are not the country we thought we were. History will be re-written. We are all accountable, but this begins in the late 1800s and goes to 1996. "White" Canada knew - on somebody's purpose - nothing about this. We weren't taught it; it was hardly ever mentioned. All of those Governments, and all of those Churches, for all of those years, misused themselves. They hurt many children. They broke up many families. They erased entire communities. It will take seven generations to fix this. Seven. Seven is not arbitrary. This is far from over. Things up north have never been harder. Canada is not Canada. We are not the country we think we are. (Statement by Gord Downie, n.p.)

Gord Downie began Secret Path as ten poems. The poems, then, became lyrics for ten songs he recorded with producers Kevin Drew and Dave Hamelin. In 2014, Gord and his brother Mike presented the recently finished music to Canadian comic artist Jeff Lemire and invited him to illustrate Chanie's story. The idea of retelling this heartbreaking and quite unknown story had a special appeal to the comic artist, who thought the universal power of the comics medium could help start a process of reconciliation between Canada and its indigenous people:

Before we left the coffee shop I knew I was going to do it. I had to. Chanie's story is one that will not let you go once you hear it. It's a story that can't be ignored. And yet, somehow, it has been ignored. By nearly all of us. ...Gord's haunting songs introduced me to Chanie Wenjack. Music is universal. It crosses languages and cultures and speaks to everyone, and I've always felt the medium of comics could do the same. It's our hope that one day Secret Path will be taught in schools and that it will help to shed a light on this all too often ignored part of Canada's past. (Statement by Jeff Lemire, n.p.)

Lemire's eighty-eight page graphic novel published by Simon \& Schuster Canada has been released and sold together with Downie's album in a deluxe vinyl and book edition, and also as a book with album download. Interestingly, the book format reminds us of a vinyl album dimensions: $30 \times 30 \mathrm{~cm}$.

Next, the story was also adapted into a $45 \mathrm{~min}$. animated film that puts together Downie's poetry and music with Lemire's powerful visual representation of Chanie Wenjack. The moving film was broadcast by $\mathrm{CBC}$, followed by a documentary footage of Downie visiting the Wenjack family in Ogoki Post, Ontario, and by the panel discussion called Road to Reconciliation. ${ }^{2}$ Downie also helped promoting the project by performing a few live shows. Secret Path reached the top 5 in the Canadian chart.

It is fair to say, therefore, that although the project was mainly conceived by Gord Downie, it counted with the collaboration of several other people due to its transmedial character. The film The Secret Path, for instance 
was created, written, and directed by Gord Downie, composed by Gord Downie with Kevin Drew and Dave Hamelin, and illustrated by author Jeff Lemire. The film is executive produced by Mike Downie, Patrick Downie, Gord Downie, and Sarah Polley; produced by Entertainment One (eOne) and Antica Productions Ltd. in association with $\mathrm{CBC}$, with the participation of the Canada Media Fund and the Canadian Film or Video Production Tax Credit. Jocelyn Hamilton is executive producer for eOne Television and Stuart Coxe is executive producer for Antica Productions. Animation is directed by Justin Stephenson, produced at Solis Animation Inc. and composited by Even Steven Inc.

whereas the album and the graphic novel were credited as follows:

Words by Gord Downie; graphic novel \& illustrations by Jeff Lemire; songs by Gord Downie with Kevin Drew \& Dave Hamelin; produced and mixed by Kevin Drew \& Dave Hamelin; vocals, acoustic and electric guitars by Gord Downie; all other instrumentation by Kevin Drew \& Dave Hamelin; guest musicians: Charles Spearin - bass, Ohad Benchetrit - lap steel \& additional guitar, Kevin Hearn - additional keys, Dave "Billy Ray" Koster - drums; engineered by Nyles Spencer; recorded and mixed at the bathouse recording studios, bath, on, Canada on November 3 - November 10, 2013; November 27 - December 2, 2013; mastered by Eric Boulanger, The Bakery, Culver City, CA, USA. Art direction by Jonathan Shedletzky; design \& layout by Isis Essery; website design by Ian Porter. ${ }^{3}$

The artistic collaboration, especially between Downie and Lemire, could be especially captured in the Lyric Booklet, in which Downie's first drafts for the lyrics were put side by side with some of Lemire's most iconic images of the graphic novel, as in Fig. 1.

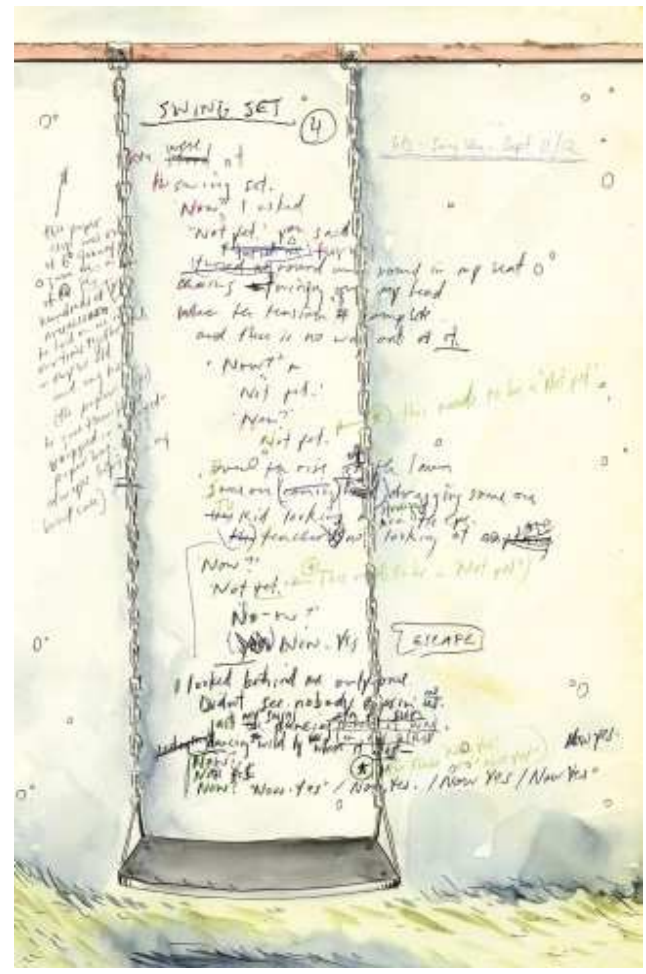

Fig. 1: A page from Secret Path - Lyrics Booklet 
Together with the Wenjack family, Downie created the The Gord Downie \& Chanie Wenjack Fund (DWF) with the objective of reconciliating indigenous and non-indigenous people. All proceeds from the sale of Secret Path were meant to be donated to the fund. On December 2016, Downie was granted an eagle feather for his support of the indigenous peoples of Canada. He was also given an aboriginal name, Wicapi Omani, which in Lakota means "man who walks among the stars" (Tasker, n.p.).

Downie kept fighting for the indigenous people until October $17^{\text {th }}, 2017$, when he passed away at age 53. His death was mourned by many Canadians, including the prime-minister Justin Trudeau, who released a tribute statement on Twitter "There will never be another one like you, Gord. Rest in peace my friend."

One could argue that Secret Path would be a multimedial (or, less usual, a plurimedial) project. In fact, in the various fields interested in this subject human sciences, sociology, semiotics, communication and media studies -, it is not unusual to have different terminologies for the same phenomenon or process. So, why do we propose that the project Secret Path be called transmedia instead of multimedia or plurimedia?

According to Leo Hoek, in a scale of levels of interaction between text and image, the multimedia discourse describes the juxtaposition of the two sign systems, which keep their separability, self-sufficiency, but not their politextuality (185). That means that only one medium or work is at play. In other words, multimedia combines coherently separable texts, composed in different media. So, first, since they combine music and lyrics, Downie's songs can be considered multimedia texts. The lyrics booklet is another example of a multimedia text similar to illustration, a combination of coherently separable words and images.

Second, mixmedia texts "contain complex signs in different media that would not reach coherence or self-sufficiency outside that context" (Cluver 15). Comics could, therefore, be considered mixmedia texts. Curiously, Lemire's graphic novel does not use any speech balloons (except for a "goodbye" at the end of the book). Instead, it uses Downie's lyrics as opening for each of the ten chapters or parts of the book, and to which his drawings are related. In this sense, perhaps, we could say there would be a very thin line between considering it a mixmedia text (as typical of the comics medium, in which words and images combine in a way that if separated, they would not make sense) or a multimedia text (a series of illustrations, coherently separable from the lyrics).

Third, since it combines several media within a single medium (songs, animation, documentary), we could call The Secret Path "plurimedial". This term can be easily confused with "multimedial". Clüver explains the difference: "Whereas 'plurimediality' refers to the presence of several media within a medium such as the cinema or the opera, we call 'multimediality' the presence of several media within an individual text" (15).

Fourth, from a genetic perspective, we could also say that the animated film from The Secret Path (the film) is an adaptation of the graphic novel, as Lemire's 
work is used as a source text that is transformed into a new medium (or target text), according to its material possibilities and conventions.

However, what interests us here is not the internal configuration of each medium used in the project, nor the relation between two of them, but how the media are used to construct a relevant and coherent part of a larger transmedial project, each new medium contributing in a distinctive manner to add meaning to it.

For example, if we read Downie's lyrics or listen to his songs, individually or in a group, we will probably not understand the details of Chanie's story or even that they refer to his story at all. If we read Lemire's graphic novel, we are able to put together the lyrics and the drawings, so the drawings help us understand that the lyrics refer to an indigenous boy's sad story.

The animated film combines even further songs (lyrics + music) and images. The movement of the drawings, besides increasing the dramatic aspect of the story, offers the viewer some details and meanings that could not be seen at the graphic novel. This happens, for instance, in the chapter "son": in the graphic novel, we see the father pressing his hand against the boy's heart. Next, we see he boy lying down with both his hands pressed against his heart. In the animated film, we see that this episode brings the boy memories about his house and family; next, we see the father's hand slowly disappearing underneath the boy's hands before he lies down.

The documentary that follows the animated film extends even further our comprehension of the story. We now learn that this story happened in real life, and we finally know all the details of Chanie's journey. The discussion panel helps us understand the importance of telling a story such as this one in contemporary times: to give voice to indigenous people and other minorities in multicultural Canada and to try to build a road for reconciliation.

This supplementary relation, established by a network of different media that come together to further develop or extend meaning to a story that could (or should) not be told by one single medium - in other words, a transmedial phenomenon - is therefore my focus here.

\section{The Crew in Airplane Mode}

The cover of the bilingual edition Modo avião/Airplane Mode has three names, displayed without their respective credits, which misleadingly leads us to think that the book has three authors. However, as soon as we open it, the authorial roles are better defined:

Paintings: Rafael Coutinho

Texts: Lucas Santtana e J. P. Cuenca

Musics: Lucas Santtana

Airplane Mode is an "album-book" composed by a series of dialogues intertwined by song lyrics and images. The dialogues tell loosely connected love 
stories, in which the airplane is the background for their meeting or is simply mentioned. First, a couple (named "he" and "she") meets on an airplane; in the next dialogue, he walks on the street and thinks about her; next, he and Maria are having an affair and it is implied that they meet when they travel; next, a woman (Alice) calls a guy she had met on the airplane and they decide to go out to eat something; then, Graciela (his therapist) and the guy meet at a restaurant; next, two guys talk about girls; he finally meets Marina, and he says that each time they meet she has a different name, a different face, which means it is all but "a dream within a dream within a dream".

Using an interesting layout - in which pages unfold open, revealing the colored drawings by Rafael Coutinho - and a type of binding in which the sewing is apparent, Airplane Mode perfectly combines the vague description of the characters - we know nothing of their lives, where they are coming from or where they are going and why - with the fading contour lines of the drawings (Fig. 2).



Fig. 2: A drawings plate by Rafael Coutinho in Airplane Mode

Signing the introductory text "more alive than ever", architect Guilherme Wisnik reminds us that the experience of travelling by airplane has changed over the years. Back in the 1960s, when flying was not very common, it was mostly related to the need to go back and to miss someone. However, in Airplane Mode, a "promiscuous work of art", Wisnik warns the reader that there is no difference between leaving and arriving; drowned in our own chaotic lifestyles, we may no longer discern between work and home, day and night, here and there.

Airplane Mode is, first of all, a critique of the way people have been dealing with technology: "people who are proud of being too busy, far too connected and yet, so detached from others, represented by profiles and avatars on little viewing screens. These clones have long distance interactions, but where are their souls?" (Dialogue "street").

Second, being on the airplane offers a state of suspension, a dream-like momentum in which time and space are erased or barely seen/felt: "For me it's like as if this place had no time, no space. Think about it: we're not in the time zone we left or where we're going. We're not in any country; this is a non-place. ...We're in a sort of limbo, in airplane mode." (Dialogue "airplane", no page number) In this sense, being on "airplane mode" offers the possibility to escape from places, 
times and, most importantly, from our everyday routine: "Can anyone turn off this world for a moment? / Go into airplane mode" (Song "airplane mode").

Besides the book with the dialogues, lyrics and drawings, Airplane Mode is also a music DVD, with ten songs by Lucas Santtana, eight of which are present (in the form of lyrics) in the book. A second version of the DVD is called Airplane Mode (complete story), available both in English and in Portuguese, which puts together the songs with the dialogues in the book, including ambience sound. The musician calls this an innovative initiative, as the narrative results from the text being intertwined with the songs: "They do not work as a musical or an opera, in which the lyrics of the songs continue the literary text of the scenes" (Oliveira; Paula, n.p.). ${ }^{4}$

The experience of hearing the dialogues recorded with ambience sound is similar to watching a film without images, as if we were in the cinema, just with our eyes closed. A technical resource helps granting a realistic feeling to the experience: the fact that the DVD was all recorded with binaural microphones.

Used mostly in cinema to capture the ambience sound, this technique allows for a $360^{\circ}$ (as opposed to the $180^{\circ}$ of normal microphones) hearing, which results in a surround effect that approximates the recording to the way humans hear. Airplane Mode was the first album in the history of Brazilian music to use this kind of microphones, a process to which Santtana himself collaborated: "I recorded the audio clips myself inside the airplane, on the beach and in the restaurant, for instance" (Carvalho, n.p.). ${ }^{5}$

To increase the similarity with the film medium, Santtana invited several well-known Brazilian actors to - together with him - impersonate the characters: Patrícia Pillar plays Maria; Georgette Fadel is Graciela; Mariana Lima is Alice; Aury Porto is The other; Maria Manoella is the women of the plane; Cadu Fávero is the waiter; and Carolina Bianchi plays the role of Marina. In this sense, more than an "album-book" or an "audio-book", Airplane Mode is an "album-audiofilm-book" that combines illustration, music, cinema/dramatic art and literature.

The ambience sound is also a fundamental element in the characterization of this project as transmedial. This is because, if it were not for the ambience sound, we could perhaps say that the DVD Airplane Mode (complete story) was simply an adaptation of the book to the DVD format, or from a verbovisual to an auditory sign system. However, with the sounds recorded from the ambient, we have "a story that goes beyond the songs, complementing them" (Wisnik, n.p.). The DVD offers an expanded version of the book, which not only includes the ambience sounds, but also the voices of the characters, and the oral marks typical of informal dialogues, such as intonations and accents. These elements cooperate to enhance our comprehension of the story: our interpretation of a dialogue may be transformed, for example, by the tone of voice an actor uses in a certain sentence.

As the case with Airplane Mode demonstrates, the interdependency among media for the construction of meaning is one of the basilar characteristics of the transmedial phenomena. So, from a consumption perspective, the understanding of Airplane Mode as a transmedial narrative may only be "complete" when all the 
media involved in the project - texts, songs and dialogues with ambience sounds - are brought together. ${ }^{6}$

From a production perspective, the transmedial character of the project is evinced by the several roles played by one of its creators, Lucas Santtana. Besides recording the ambience sound, playing a character, writing the lyrics and conceiving the musical arrangements for the songs, he also helped J.P. Cuenca elaborated the dialogues.

This collaboration was a new experience for all three artists involved. For example, when questioned if he would like to follow a career as a writer, Santtana replies:

I intend to write a book, but not now. I want to continue working with this audiofilm format. When I had the idea for the project, I did a lot of research and found almost nothing on the internet. I looked for things that had this format, with a literary text, music and everything. I did not find it. It was bad because I had no reference at all. I was kind of doing and learning. (Carvalho, n.p. $)^{7}$

J.P. Cuenca explains the process of development of the project, as well as his reactions to it:

The texts were conceived after the compositions. The disc already had a backbone. I wrote the dialogues, then Lucas adjusted. It was a text made with four hands (...) It's something quite new for me or for the three of us. Each of us is treading on unknown terrain. (Oliveira, Paula, n.p.) ${ }^{8}$

Finally, for Rafael Coutinho, the process of creation of the illustrations was quite sensitive and exploratory:

The first temptation it gives you is to try to take the said images, the words that are said in the music, and transpose them, translate them into images. And it seemed to me a rather empty or weakened exercise of the whole experience... And [I was] discovering in this choreography, in the clothes, in the very graphic conduction of the thing, to have this dialogue with the instruments, with the rhythm, with the sonority that each song proposed. (Moso avião, n.p. $)^{9}$

The specificities of the project were a particular challenge to Coutinho, who had to create illustration panels that were at the same time related to both songs and text, but that did not simply repeat their elements. His concern was to make the illustrations integrate perfectly into the project, to make them all interdependent: “(...) the challenge was to try not only to make the drawings of the scenes, but also to try to translate Lucas's songs into an image. And all the effort in the book was to get it to talk to the disc intimately, [turn] it into a piece so fundamental to the disc as the text was" (Modo avião, n.p.). ${ }^{10}$ 


\section{Final Considerations}

While observing contemporary media productions in the entertainment industry, one notices a considerable growth in the number of transmedial franchises, projects that combine several media that work together in a coherent and cohesive manner to tell a story. In an era of hybrid cultural products immersed in ever more complex textual networks, this medial cooperation reflects the new ways of creating, telling, retelling and consuming (listening to/watching/playing with etc.) stories.

In relation to the modes of consumption, transmedia franchises create, as Jenkins alerts us, a migratory audience, willing to search for and consume several products within the franchise, in order to experience a more complete or detailed version of the story. Transmedia becomes, then, a financially interesting project for producers, as they attract audiences from different niches and distinct media.

In terms of production, transmedia franchises demand that authors (or developers, producers, creators, artists) either learn new medial competences or team up with other professionals in order to create and develop successful transmedia projects. Considering the role of the Author-God as Barthes conceived it, it is perhaps the case that the Author is not dead, but that there are many Authors or several deities.

Both selected projects raise relevant thematic issues. On one hand, Secret Path retells a true story that is meant to represent several other true stories alike; it highlights a painful past with a message for Canadians to listen to their multiple voices, in order to build a better future. On the other hand, Airplane Mode proposes a change on the way we live in the present; it defends that we disconnect from our electronic gadgets and reconnect with ourselves.

Most important, in my analysis I also observed a similarity in the media used in the two projects: both make use of books with lyrics and wordless comics/ illustrations - in unconventional book formats; both use songs composed and played by one of their own creators; both use the YouTube to provide additional material (animation, dramatic representation) related to the book.

In fact, the idea that the two projects - released just a few months apart in different countries - are composed of similar media that relate in analogous ways is quite intriguing. This perhaps corroborates the now inevitable movement towards collaborative productions in contemporary media products, culture and industry. However, whether in the form of transmedial franchises, multimedia texts or else, collaborative productions will remain an overlooked phenomenon, for as long as academic disciplines persist with the more conservative notions of authorship, consumption and media boundaries.

\section{Notes}

1. Although it does not depend on new technologies (one can perfectly create a narrative that begins as episodes in a magazine or newspaper, continues in a book and ends in a comic book), transmedia finds a favorable environment in new media - such as the Internet, digital games, mobile devices etc. 
2. Available at: http://www.cbc.ca/secretpath.

3. Available at: http://secretpath.ca/.

4. “Elas não funcionam como num musical ou ópera, em que a letra da canção é uma continuação do texto literário das cenas.” My translation.

5. "Eu mesmo gravei trechos dos áudios no avião, na praia e no restaurante, por exemplo." My translation.

6. The idea of a layered or expanded comprehension in transmedial franchises is also present in Em busca da experiência expandida: revisitando a adaptação por meio da franquia transmidiática, available at $<$ https://bit.ly/2KbR9aL $>$.

7. “Tenho a pretensão de escrever um livro, mas não agora. Quero continuar trabalhando com esse formato de audiofilme. Quando eu tive a ideia para o projeto, fiz várias pesquisas e não encontrei quase nada parecido na internet. Busquei coisas que tivessem esse formato, com um texto literário, música e tudo mais. Não encontrei. Foi ruim porque eu não tinha referência nenhuma. Meio que fui fazendo e aprendendo." (My translation.)

8. "Os textos foram concebidos depois das composições. O disco já tinha uma espinha dorsal. Escrevi os diálogos, depois o Lucas mexeu. Ficou um texto a quatro mãos... É algo bastante inédito para mim ou para os três. Cada um de nós está pisando em terreno desconhecido." (My translation.)

9. “A primeira tentação que dá é você tentar pegar as imagens ditas, as palavras que são ditas na música, e transpor elas, traduzir elas em imagens. E me parecia um exercício um pouco vazio esse ou enfraquecido da experiência toda. ... E [fui] descobrindo nessa coreografia, nas roupas, na própria condução gráfica da coisa, a ter esse diálogo com os instrumentos, com o ritmo, com a sonoridade que cada música propunha." (My translation).

10. “... o desafio era tentar não só fazer os desenhos das cenas, como tentar traduzir as músicas do Lucas em imagem. E todo esforço do livro era fazer com que ele conversasse com o disco intimamente, ele fosse uma peça tão fundamental ao disco quanto o texto era." My translation.

\section{References}

Carvalho, João Paulo. "Lucas Santtana mescla música, cinema, arte e literatura em novo disco”. O Estado de S.Paulo, May 31, 2017. Available at: https:/goo.gl/ cWo0NR.

Clüver, Claus. “Intermidialidade”. Pós: Belo Horizonte, v. 1, n. 2,(nov. 2011.): 8-23.

Coutinho, Rafael; Santtana, Lucas; Cuenca, João Paulo. Modo avião. Ilustr. Rafael Coutinho. São Paulo: Lote 42, 2017.

Dena, Christy. Transmedia Practice: Theorising the Practice of Expressing a Fictional World across Distinct Media and Environments. 2009. PhD Thesis (Doctorate in Digital Culture). School of Letters, Art and Media, University of Sydney, Sydney, 2009.

Downie, Gordon; LEMIRE, Jeff. Secret Path. Illustr. Jeff Lemire. Toronto: Simon \& Schuster Canada, 2016.

Evans, Elizabeth. Transmedia Television: Audiences, New Media and Daily Life. New York/London: Routledge, 2011.

Figueiredo, Camila. Em busca da experiência expandida: revisitando a adaptação por meio da franquia transmidiática. 2016. $\mathrm{PhD}$ Thesis (Doctorate in Comparative Literature). Faculty of Letters, Universidade Federal de Minas Gerais, 2016. Available at: https://bit.ly/2KbR9aL. 
Hoek, Leo. "A transposição intersemiótica: por uma classificação pragmática". Arbex, Márcia (ed.). Poéticas do visível: ensaios sobre a escrita e a imagem. Belo Horizonte: Programa de pós-graduação em Letras: Estudos Literários: 2006. 167-189.

Jenkins, Henry. Convergence Culture: Where Old and New Media Collide. New York and London: New York University Press, 2006.

"Transmedia Storytelling: Moving characters from books to films to video games can make them stronger and more compelling". MIT Technology Review. Jan. 15, 2003. Available at: https://goo.gl/L3Q36X.

Transmedia 202: Further Reflections. Confessions of an Aca-Fan: The Official Weblog of Henry Jenkins, Aug. 1, 2011. Available at: http://henryjenkins. org/2011/08/defining_transmedia_further_re.html.

Modo avião: a arte de Rafael Coutinho. YouTube. July 7, 2017. Available at: https:// www.youtube.com/watch? $v=$ nrxF3_6fsUE.

Murray, Janet. Hamlet on the Holodeck. Cambridge: The MIT Press, 1998.

Muurray, Simone. The Adaptation Industry: The Cultural Economy of Contemporary Literary Adaptation. New York: Routledge, 2012.

Oliveira, Rebeca; Paula, Alexandre de. "Lucas Santtana mistura música, literatura e artes plásticas em 'Modo avião"'. Correio Braziliense, July 10, 2017. Available at: https://goo.gl/Nu6yJd.

Producers Guild of America. Code of Credits - New Media. Board of Directors, 2010. Available at: http://www.producersguild.org/?page $=$ coc_nm

STATEMENT by Gord Downie, Ogoki Post, Ontario, September 9, 2016. Available at: http://secretpath.ca/\#Home.

Statement by Jeff Lemire, 2016. Available at: http://secretpath.ca/\#Home.

Tasker, John Paul. "Man who walks among the stars": AFN honours tearful Gord Downie, CBC News. Dec. 06, 2016. Available at: https://goo.gl/tC8df1.

Wisnik, "more alive than ever". In: Coutinho, Rafael; Santtana, Lucas; Cuenca, João Paulo. Modo avião. Ilustr. Rafael Coutinho. São Paulo: Lote 42, 2017, n.p.

Recebido em: 05/11/2017

Aceito em: 23/04/2017 